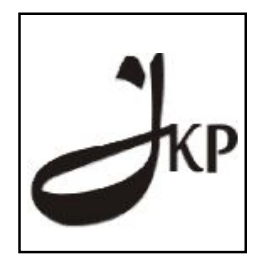

Jurnal Konseling dan Pendidikan

ISSN Cetak: 2337-6740 - ISSN Online: 2337-6880

http://jurnal.konselingindonesia.com

Volume 2 Nomor 3, November 2014, HIm 31-36

Info Artikel:

Diterima 06/11/2014

Direvisi 12/11/2014

Dipublikasikan 30/11/2014

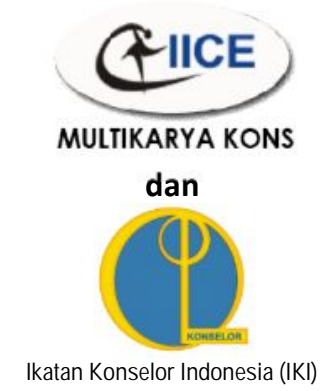

\title{
Counseling Services for Women in Marriage Age
}

Frischa Meivilona Yendi, Zadrian Ardi \& Ifdil

Universitas Negeri Padang

Abstract

Marriage is a bond between the outer and inner man as a husband who has not aged 25 years and women 21 years old wife is not with the purpose of achieving happiness. Marriage and family counseling is a profession that will be developed in Indonesia. Counseling emphasizes on changes contained in the family system. Stages counseling, theory and dynamics as well as the use of counseling skills in marriage and family counseling has similarities with individual counseling and group counseling.

Keyword: Marriage age, Adulthood, Family counseling

Copyright (C) 2014 IICE - Multikarya Kons (Padang - Indonesia) dan IKI - Ikatan Konselor Indonesia - All Rights Reserved

Indonesian Institute for Counseling and Education (IICE) Multikarya Kons

\section{PENDAHULUAN}

Masa dewasa merupakan salah satu periode dalam rentangan kehidupan manusia, dimana individu meninggalkan masa remajanya. Masa dewasa merupakan masa atau periode yang terpanjang dalam keseluruhan rentang hidup seorang individu, yaitu antara lebih kurang 18 tahun hingga individu itu meninggal dunia. Namun, sama halnya dengan masa remaja, para ahli menemukan kesulitan untuk menentukan kapan masa dewasa itu dimulai. Hal ini karena setiap kebudayaan berbeda-beda dalam menentukan kapan seseorang mencapai status dewasa secara formal. Pada sebagian besar kebudayaan kuno, status ini tercapai apabila pertumbuhan pubertas telah selesai atau setidak-tidaknya sudah mendekati selesai dan apabila organ kelamin anak telah mencapai kematangan serta mampu berproduksi. Desmita (2008:3) menjelaskan bahwa dalam kebudayaan Amerika, seorang anak dipandang belum mencapai status dewasa kalau ia belum mencapai usia 21 tahun. Sementara itu dalam kebudayaan Indonesia, seseorang dianggap resmi mencapai status dewasa apabila sudah menikah, meskipun usianya belum mencapai 21 tahun.

Menurut Santrock (2002:4) setidaknya ada dua kriteria yang harus terpenuhi untuk menunjukkan akhir masa remaja dan permulaan dari masa dewasa, yaitu kemandirian ekonomi dan kemandirian dalam membuat keputusan. Kemandirian ekonomi ditandai dengan pekerjaan yang berpenghasilan yang dimiliki oleh seseorang yang telah menginjak usia dewasa. Sedangkan kemandirian dalam membuat keputusan ditandai dengan kemantapan seseorang dalam pengambilan keputusan yang berhubungan dengan cinta atau pasangan hidup.

Terlepas dari perbedaan dalam penentuan waktu dimulainya status kedewasaan tersebut, pada umumnya psikolog membagi masa dewasa atas tiga periode, seperti yang dijelaskan oleh Feldman (dalam Santrock, 2007:6), yaitu early adulthood (masa dewasa awal) sekitar usia 20 tahun dan berlangsung sampai sekitar usia 40-45 tahun; middle adulthood (pertengahan masa dewasa) sekitar usia 40-45 sampai sekitar usia 65 tahun; dan old age (masa dewasa lanjut atau masa tua) sekitar usia 65 tahun sampai meninggal.

Masa dewasa awal disebut usia reproduktif karena pada masa ini sebagian besar individu cenderung memilih untuk menikah dan berperan sebagai orangtua. Hal ini sesuai dengan pendapat Hurlock (2012:278) bahwa di antara banyak tugas perkembangan orang dewasa awal, tugas-tugas yang berkaitan dengan pekerjaan 
dan hidup berkeluarga merupakan tugas yang sangat banyak, sangat penting dan sangat sulit diatasi. Dengan demikian, tugas perkembangan pada periode dewasa awal adalah memilih pasangan hidup, membentuk keluarga dan mengelola sebuah rumah tangga.

\section{PERNIKAHAN USIA MUDA}

\section{Pengertian Pernikahan Usia Muda}

Pernikahan merupakan proses awal pembentukan suatu rumah tangga yang kelangsungannya sangat tergantung dari kesiapan, kematangan dan kualitas mental. Untuk mencapai pernikahan yang bahagia diperlukan persiapan baik dari pihak pria maupun pihak wanita. Oleh karena itu, baik pria maupun wanita harus sudah benarbenar siap dan matang baik secara fisik maupun psikis untuk melakukan pernikahan.

Pernikahan atau perkawinan merupakan salah satu variabel yang dapat mempengaruhi proses pendewasaan pada seseorang. Lebih lanjut lagi diterangkan dalam Undang-Undang No. 1 Tahun 1974 tentang Perkawinan Pasal 7 Ayat 1 bahwa "Perkawinan hanya diizinkan bila pihak pria mencapai umur 19 (sembilan belas) tahun dan pihak wanita sudah mencapai usia 16 (enam belas) tahun." Selanjutnya dalam Peraturan Menteri Agama Republik Indonesia No. 11 Tahun 2007 tentang Pencatatan Nikah Pasal 8 dijelaskan bahwa "Apabila seorang calon suami belum mencapai umur 19 (sembilan belas) tahun dan seorang calon isteri belum mencapai umur 18 (delapan belas) tahun, harus mendapat dispensasi dari pengadilan". Pasal-pasal tersebut sangat jelas hampir tak ada alternatif penafsiran, bahwa usia yang diperbolehkan menikah di Indonesia untuk pria 19 (sembilan belas) tahun dan untuk wanita 16 (enam belas) atau 18 (delapan belas) tahun.

Berdasarkan peraturan tersebut, Badan Kependudukan dan Keluarga Berencana Nasional atau disingkat menjadi BKKBN melalui promosi di media cetak dan media eletronik pada tahun 2013 mengemukakan bahwa usia yang ideal untuk melakukan pernikahan adalah usia antara 21-25 tahun bagi wanita dan usia 25-30 tahun bagi pria. Menurut beberapa sumber data menunjukkan usia wanita menikah di Indonesia masih tergolong usia muda, yaitu di bawah 21 tahun. Pernikahan di bawah 21 tahun sering disebut sebagai pernikahan usia muda. Hal ini disebabkan secara kesehatan reproduksi bisa dikatakan masih terlalu muda, secara mental sosial belum siap dan secara ekonomi juga biasanya belum mapan. Sejalan dengan hal itu, Peraturan Menteri Agama Republik Indonesia No. 11 Tahun 2007 tentang Pencatatan Nikah Pasal 7 juga telah menjelaskan bahwa "Apabila seorang calon mempelai belum mencapai umur 21 (dua puluh satu) tahun, harus mendapat izin tertulis kedua orangtua". Izin ini sifatnya wajib, karena usia itu dipandang masih memerlukan bimbingan dan pengawasan orangtua/wali.

Sebelum memasuki jenjang pernikahan, seseorang sudah dihadang oleh persoalan yang berhubungan dengan penyesuaian, baik terhadap calon istri atau suami, maupun terhadap orang-orang lain yang mempunyai hubungan, beserta norma-norma dan nilai-nilai sosial yang berlaku. Demikian juga selama menjalani hidup berumah tangga, sering timbul masalah yang berhubungan dengan konflik dalam kehidupan pernikahan yang dipicu oleh banyak faktor. Selain itu, berdasarkan wawancara dengan salah seorang Bidan yang bertugas di Klinik Nasywa Kota Sungai Penuh Provinsi Jambi pada tanggal 21 Juni 2013 diperoleh informasi bahwa kurangnya kesiapan mental pada beberapa calon ibu dalam menghadapi kelahiran anaknya dan sikapnya terhadap kehamilan merupakan masalah-masalah yang sering timbul pada masa dewasa awal ini.

Jumlah kasus perceraian di Indonesia meningkat tajam. Salah satu faktor yang mempengaruhinya adalah pernikahan di usia muda. Hal tersebut disampaikan oleh Sudibyo Alimoeso, selaku pelaksana tugas (Plt) Kepala BKKBN pada Forum Bakohumas "Hari Keluarga" dengan tema Membangkitkan Kebersamaan Keluarga Kecil Bahagia Sejahtera di Halim Perdanakusumah, Jakarta Timur, Kamis 30 Mei 2013 (dalam nasional.inilah.com/read/detail/1994675/bkkbn-ajak-masyarakat-hindari-pernikahan-usia-dini\#.Ug8mJ1r-LtJ, 2013). Tidak jauh berbeda dengan hasil observasi awal yang dilakukan pada tanggal 13 Agustus 2013 di Pengadilan Agama Kabupaten Kerinci, bahwa sepanjang tahun 2011-2012 terjadi 48 kasus perceraian di Kecamatan Air Hangat Timur, yang paling banyak dialami oleh pasangan dengan usia 20-25 tahun.

Berdasarkan observasi awal yang dilakukan peneliti pada tanggal 26 Juni 2013 di Kecamatan Air Hangat Timur Kabupaten Kerinci diperoleh informasi bahwa dari 170 peristiwa pernikahan di Kantor Urusan Agama 
(KUA) Kecamatan Air Hangat Timur Kabupaten Kerinci pada tahun 2012/2013, sebanyak 118 wanita yang menikah pada usia di bawah 21 tahun, yaitu 23 wanita pada usia 20 tahun, 26 wanita pada usia 19 tahun, 32 wanita pada usia 18 tahun, 26 wanita pada usia 17 tahun, dan 11 wanita pada usia 16 tahun. Hal ini menunjukkan rata-rata wanita di kecamatan tersebut masih menikah pada usia di bawah 21 tahun. Menurut salah seorang petugas di KUA tersebut, jumlah wanita yang menikah di usia muda selalu mengalami peningkatan dari tahun ke tahun.

\section{Faktor Penyebab Terjadinya Pernikahan Usia Muda}

Banyak faktor yang mempengaruhi keputusan wanita untuk menikah pada usia tersebut, diantaranya adalah faktor sosial, ekonomi dan budaya. Faktor sosial yang berpengaruh terhadap perkawinan usia muda pada wanita adalah faktor pendidikan. Rendahnya pendidikan orangtua dan remaja mendorong untuk melakukan pernikahan pada usia di bawah 21 tahun, perempuan remaja yang tidak melanjutkan sekolah akhirnya menganggur, karena sulitnya mencari pekerjaan.

Faktor ekonomi yang mempengaruhi pernikahan adalah jumlah pendapatan orangtua. Orangtua yang berpendapatan rendah biasanya tidak mampu membiayai sekolah anaknya sehingga orangtua ingin anaknya segera menikah, ingin lepas dari tanggungjawab dan orangtua berharap mendapat bantuan secara ekonomi. Pada umumnya mereka hanya tamat SD, SMP atau SMA. Berdasarkan data catatan pernikahan dari KUA Kecamatan Air Hangat Timur Kabupaten Kerinci tahun 2012-2013 diperoleh keterangan tentang jenjang pendidikan wanita yang mengalami pernikahan usia muda, yaitu 45 wanita yang tamat SMA, 50 wanita yang tamat SMP, dan 26 wanita yang tamat SD. Dengan kondisi tersebut daripada menjadi beban keluarga akhirnya orangtua menganjurkan anaknya untuk segera menikah.

Faktor budaya yang mempengaruhi perkawinan adalah tradisi di daerah setempat. Berdasarkan hasil wawancara dengan salah seorang Ibu dari wanita yang menikah usia muda pada tanggal 10 Agustus 2013 diperoleh keterangan bahwa pernikahan usia muda yang dialami oleh putrinya dipengaruhi oleh lingkungan setempat yang berpendapat bahwa malu menjadi perawan tua, lebih baik jadi janda muda daripada perawan tua. Jadi, konotasi perawan tua merupakan momok bagi sebagian masyarakat yang tinggal di Kecamatan Air Hangat Timur Kabupaten Kerinci.

Beberapa wanita di Kecamatan Air Hangat Timur Kabupaten Kerinci telah menikah pada usia muda. Berdasarkan hasil wawancara dengan petugas KUA Kecamatan Air Hangat Timur Kabupaten Kerinci pada tanggal 15 Agustus 2013 diperoleh keterangan bahwa faktor penyebab terjadinya pernikahan usia muda berbedabeda, diantaranya rendahnya pendidikan orangtua dan remaja di Kecamatan Air Hangat Timur Kabupaten Kerinci mendorong untuk melakukan pernikahan pada usia di bawah 21 tahun. Selama menjalani hidup berumah tangga, sering timbul masalah yang berhubungan dengan konflik dalam kehidupan pernikahan yang dipicu oleh banyak faktor. Selain itu, kurangnya kesiapan mental pada beberapa calon ibu dalam menghadapi kelahiran anaknya dan sikapnya terhadap kehamilan, juga merupakan masalah-masalah yang sering timbul pada masa dewasa awal ini dengan adanya pernikahan usia muda pada wanita di Kecamatan Air Hangat Timur Kabupaten Kerinci.

\section{Kondisi Pribadi Wanita pada Pernikahan Usia Muda}

Pernikahan usia muda terjadi pada wanita usia dibawah 21 tahun. Pada usia rentangan usia 16-20 tahun, seorang wanita mulai menemukan nilai-nilai hidup baru, sehingga semakin jelaslah pemahaman tentang keadaan diri sendiri. Menurut Kartono (2006:66) pada periode ini seseorang mulai bersikap kritis terhadap objek-objek di luar dirinya dan ia mampu mengambil sintese antara dunia luar dan dunia internal. Pada perkembangan ini dibangun dasar-dasar yang akan menentukan pembentukan kepribadiannya. Oleh karena itu, periode usia tersebut merupakan perjuangan terakhir bagi remaja menjelang kedewasaannya.

Masa dewasa awal sebenarnya merupakan kelanjutan dari masa remaja. Menurut Santrock (2007:4), setidaknya ada dua kriteria yang harus terpenuhi untuk menunjukkan akhir masa remaja dan permulaan dari masa dewasa, yaitu kemandirian ekonomi dan kemandirian dalam membuat keputusan. 
Hal tersebut sesuai dengan pendapat Sigmund Freud (dalam Prayitno, 2006:4) mengungkapkan seseorang yang telah dewasa itu mampu bertanggung jawab terhadap segala tingkah laku dan pekerjaan atau karir yang dilakukannya sehari-hari dan terhadap cintanya yang telah dinyatakannya pada seseorang. Pada fase dewasa awal ini manusia menjadi matang dalam berpikir untuk memikul tanggung jawab dan cinta terhadap pasangannya yang telah menjadi pilihannya, selanjutnya akan melakukan pernikahan dan membentuk keluarga.

Sejak seseorang menyandang status dewasa, ia diharapkan memiliki kesiapan untuk menerima kewajiban dan tanggung jawab sebagai orang dewasa, yang ditunjukkan dengan pola-pola tingkah laku sebagaimana yang berlaku pada kebudayaan sekitarnya. Sampai saat ini belum ada rumusan tugas-tugas perkembangan yang khas bagi orang dewasa sesuai dengan karakteristik kebudayaan Indonesia, secara teoritis rumusan tugas-tugas perkembangan yang diajukan oleh Robert J. Havighurst agaknya dapat dijadikan acuan. Dalam hal ini, Havighurst (dalam Santrock, 2007:16) menyebutkan 8 tugas perkembangan orang dewasa awal, yaitu:

a. Memilih jodoh

b. Belajar hidup bersama dengan suami atau istri

c. Mulai hidup berkeluarga

d. Membesarkan anak

e. Mengelola rumah tangga

f. Mulai bekerja

g. Memikul tanggung jawab sosial

h. Menemukan kelompok sosial yang cocok dengan nilai-nilai yang dianutnya.

Tugas perkembangan periode dewasa awal yang ditandai kemandirian secara karir dan cinta dapat dicapai dengan optimal oleh seorang individu apabila tugas perkembangan pada periode sebelumnya, yaitu periode remaja akhir telah terpenuhi. Oleh sebab itu, disarankan bagi wanita untuk tidak menikah pada usia dibawah 21 tahun.

\section{Masalah dalam Pernikahan Usia Muda}

Masalah akan dialami seseorang apabila hal yang terjadi padanya tidak sesuai dengan yang diharapkannya. Menurut Winkel (1997:334) masalah adalah suatu kondisi, situasi suasana yang tidak mengenakkan yang dapat mengganggu berjalan dan berkembangnya kehidupan.

Wanita yang menikah pada usia muda menghadapi problem atau masalah. Charoters, et al. (dalam Kertamuda, 2009:31) mengemukakan bahwa dampak dari seorang wanita yang melahirkan di usia muda memiliki perasaan sangat mendalam pada anak yang dilahirkannya. Hal tersebut sering membuat mereka dibebani oleh tanggung jawab sebagai orangtua, termasuk sebagai pengasuh dan model bagi anak-anaknya.

Untuk mengatasi masalah yang terjadi, maka ibu muda perlu menyeimbangkan antara tanggung jawab sebagai orangtua dan kebutuhan akan pendidikan lanjut, menjaga keamanan sosial ekonomi, serta memenuhi kebutuhan, baik semosional dan fisik dari anaknya. Hal ini tidak mudah karena menurut Furstenberg, et al. (dalam Kertamuda, 2009:32) remaja yang menjadi orangtua sering menghadapi lingkungan yang tidak nyaman karena mereka berperan sebagai orangtua dan juga bertanggung jawab untuk memenuhi segala kebutuhan, padahal mereka tidak mempunyai pendidikan yang cukup dan tidak pula bekerja.

Berdasarkan uraian tersebut dapat dihubungkan dengan pendapat Mooney (dalam Prayitno dan Amti, 1994:242) yang mengidentifikasi 330 masalah yang sering terjadi pada seseorang individu kemudian dibagi kembali oleh Prayitno dkk (1996:2) dalam beberapa bidang masalah melalui Alat Ungkap Masalah (AUM) Umum Masyarakat, yaitu:

a. Jasmani dan Kesehatan (JDK)

b. Diri Pribadi (DPI)

c. Hubungan Sosial dan Kemasyarakatan (HSK)

d. Ekonomi dan Keuangan (EDK)

e. Keadaan dan Hubungan dalam Keluarga (KHK)

f. Pendidikan, Karir, dan Pekerjaan (PKP)

g. Agama, Nilai, dan Moral (ANM)

h. Hubungan dengan jenis Kelamin lain dan Perkawinan (HKP)

i. Waktu Senggang (WSG). 


\section{BIMBINGAN DAN KONSELING UNTUK PERNIKAHAN USIA MUDA}

Pernikahan di usia yang masih muda dapat menimbulkan resiko kesehatan bagi wanita, terutama apabila terjadi kehamilan di usia muda. Menurut Kertamuda (2009:31) hal tersebut dikarenakan kematangan secara biologis yang belum betul-betul sempurna dapat mengakibatkan kematian saat melahirkan. Selain itu, kematangan secara pribadi juga masih belum maksimal. Untuk itu, setiap pasangan perlu matang secara pribadi dalam menghadapi lingkungan yang berbeda satu sama lain. Keluarga besar terkadang memiliki peran yang kuat dalam kehidpan rumah tangga pasangan suami istri, sehingga keputusan keluarga cenderung lebih dominan. Permasalahan-permasalahan yang terjadi perlu disikapi secara matang untuk menghindari hal-hal yang tidak diinginkan dari pasangan tersebut.

Selain itu, terdapat hambatan-hambatan yang dihadapi sebagai seorang remaja yang harus berperan sebagai ibu muda, diantaranya adalah bentuk identitas, kegelisahan pada kemandirian dan pubertas. Pada kenyataannya tidak mudah menjadi orangtua di usia muda karena dapat meningkatkan resiko megatif pada mereka untuk menjadi orangtua yang cakap. Apabila pasangan tidak dapat menangani apa yang terjadi pada kehidupan mereka, maka sudah pasti kehidupan pernikahan mereka akan goyah.

Penanganan secara intensif perlu diberikan kepada pasangan suami istri muda yang menghadapi masalah dalam pernikahannya. Hough dan Stevens (dalam Kertamuda, 2009:32) menggaris bawahi dua tipe sistem dukungan, yaitu formal dan informal. Sistem informal termasuk kerabat, teman-teman dan tetangga. Sedangkan, dukungan formal termasuk institusi, agensi atau program-program di luar keluarga yang mendukung.

Salah satu cara yang dapat ditempuh diantaranya adalah konsultasi dan konseling yang mendalam pada pasangan, ini merupakan salah satu jalan untuk dapat membantu menyelesaikan masalah yang dihadapi. Menurut Kertamuda (2009:32) hal tersebut bertujuan agar memperoleh gambaran secara jelas dampak psikologis dari peristiwa yang menimpa dirinya dan keluarganya. Sehingga melalui konseling diharapkan dapat memberikan bantuan atau pertolongan terhadap keadaan, perasaan serta kondisi psikologisnya dan juga rencana masa depannya.

Masalah yang dihadapi oleh pasangan dalam pernikahan dapat dientaskan melalui layanan bimbingan dan konseling. Prayitno dan Amti (1994:100) mengemukakan bahwa bimbingan adalah proses pemberian bantuan yang dilakukan oleh orang yang ahli kepada seorang atau beberapa orang individu, baik anak-anak, remaja, maupun dewasa; agar orang yang dibimbing dapat mengembangkan kemampuan dirinya sendiri dan mandiri; dengan memanfaatkan kekuatan individu dan sarana yang ada dan dapat dikembangkan; berdasarkan normanorma yang berlaku. Lalu Prayitno dan Amti (1994:106) menjelaskan bahwa konseling adalah proses pemberian bantuan yang dilakukan melalui wawancara konseling oleh seorang ahli (disebut konselor) kepada individu yang sedang mengalami sesuatu masalah (disebut klien) yang bermuara pada teratasinya masalah yang dihadapi oleh klien. Dengan demikian, layanan bimbingan dan konseling adalah proses pemberian bantuan oleh seorang konselor kepada klien dengan tujuan untuk mengembangkan potensi yang dimiliki klien dan mengentaskan masalah yang dialami klien.

Konseling pernikahan dan keluarga merupakan suatu profesi yang baru akan berkembang di Indonesia. Menurut Kertamuda (2009:119) konseling ini menekankan pada perubahan sistem yang terdapat dalam keluarga. Tahapan konseling, teori dan dinamika serta penggunaan keterampilan konseling pada konseling pernikahan dan keluarga memiliki persamaan dengan konseling individual dan konseling kelompok.

Prayitno (2004) menjelaskan tentang konseling individual sebagai salah satu layanan yang diberikan kepada seorang individu yang mengalami permasalahan peribadi dan diharapkan permasalahan tersebut dapat terentaskan. Sedangkan, konseling kelompok adalah layanan yang diberikan kepada sejumlah orang untuk membahas salah satu masalah pribadi anggota kelompok.

Berdasarkan uraian tersebut dapat disimpulkan bahwa bentuk bimbingan dan konseling yang dapat diberikan pada pernikahan dan keluarga adalah layanan konseling individual, konseling kelompok, konsultasi dan mediasi. 


\section{PENUTUP}

Kehidupan dalam pernikahan dan berkeluarga tidak akan selalu berjalan dengan mulus. Hal ini disebabkan masalah akan timbul selama kehidupan berjalan. Masalah-masalah yang timbul dapat mengakibatkan pasangan suami istri merasa tidak bahagia. Olson dan DeFrain (dalam Kertamuda, 2009:122) menyebutkan bahwa pasangan dan keluarga yang menunjukkan gejala ada masalah dalam hubungannya dengan pasangan sebaiknya segera mencari bantuan pada konselor atau terapis pernikahan. Pasangan suami istri dapat menerima bantuan sebelum masalah yang dialami menjadi bertambah parah sehingga akan mempunyai kesempatan untuk menghadapi kesulitan dan membangun hubungan yang kuat.

Sehubungan dengan hal tersebut perlu dilakukan kajian mengenai kondisi pribadi, masalah yang dialami dan kebutuhan terhadap layanan bimbingan dan konseling pada wanita dalam pernikahan usia muda. Oleh sebab itu, perlu dilakukan penelitian tentang "Kondisi Pribadi, Masalah yang Dialami dan Layanan Bimbingan dan Konseling yang Dibutuhkan Wanita dalam Pernikahan Usia Muda" terutama di Kecamatan Air Hangat Timur Kabupaten Kerinci.

\section{DAFTAR PUSTAKA}

Desmita. (2008). Psikologi Orang Dewasa. Batusangkar: STAIN Batusangkar Press

Hurlock, Elizabeth B. (2012). Psikologi Perkembangan; Suatu Pendekatan Sepanjang Rentang Kehidupan (Edisi Kelima) (Alih Bahasa: Istiwidayanti dan Soedjarwo). Jakarta: Erlangga

Kartono, Kartini. (2006). Psikologi Wanita 1; Mengenal Gadis Remaja dan Wanita Dewasa. Bandung: Mandar Maju

Kertamuda, Fatchiah E. (2009). Konseling Pernikahan untuk Keluarga Indonesia. Jakarta: Salemba Humanika

Peraturan Menteri Agama No. 11 Tahun 2007 tentang Pencatatan Nikah

Prayitno \& Amti, Erman. (1994). Dasar-dasar Bimbingan dan Konseling. Jakarta: Depdikbud

Prayitno, dkk. (1996). Pedoman AUM Umum Masayarakat. Padang: IKIP Padang

Prayitno, Elida. (2006). Psikologi Orang Dewasa. Padang: Angkasa Raya

Santrock, John W. (2002). Life Span Development: Perkembangan Masa Hidup (Jilid I) (Alih Bahasa: Achmad Chusairi dan Juda Damanik). Jakarta: Erlangga

Santrock, John W. (2007) Adolescence, Eleventh Edition (Alih Bahasa: Benectine Widyasinta). Jakarta: Erlangga

Undang-Undang No. 1 Tahun 1974 tentang Perkawinan

Winkel, WS. (1997). Bimbingan dan Konseling di Institusi Pendidikan. Jakarta: Gramedia Widiasarana Indonesia 